\title{
UNIQUE MANUSCRIPTS AND PRINTED DOCUMENTS OF UKRAINIAN MUSICAL CULTURE OF THE 18TH CENTURY: SOURCES SEARCH
}

\section{Shulgina V. D.}

\section{INTRODUCTION}

The restoration of a historically objective picture of the artistic existence of national culture at all stages of its development is an urgent need of contemporary Ukrainian cultural studies and art criticism. The new national cultural policy in Ukraine provides for the possibility of introducing into the circulation of little-known archival documents that have been artificially removed from Soviet-era scientific research. From this point of view, the study of unique documents of the history of musical culture of Ukraine of the eighteenth century is an actual property of modern cultural studies. The author focused on the coverage of particular stages of Ukrainian culture development and on his own findings of unknown or forgotten handwritten and printed music notes from the archives and libraries of Ukraine, Germany, Poland and Austria. The presented intelligence is the next stage of implementation of the project "Distinguished Figures and Cultural Monuments of Ukraine", authored and led by the rector of the National Academy of Management Personnel of Culture and Arts, Laureate of the State Prize of Ukraine, Professor V. Chernets.

The source search led the author of the study to find "Variations" by E. Belogradskaya - the first Ukrainian work of great form; three piano sonatas by M. Berezovsky; unknown autographs of V. Zaremba's piano works, rare editions from Razumovsky's collection, etc.

The author's source-based approach to the study of the heritage of prominent cultural figures of Ukraine contributed to the presentation of manuscript music notes and family documents from the Razumovsky's Collection from the holdings of the Rare Book Division and the Vernadsky National Library of Manuscripts named after V. Vernadsky (NBUV). For the first time, the works of E. Belogradskaya and M. Berezovsky from the archives of Germany and Poland became the subject of analysis.

It is important to note that the vast majority of archival documents were first introduced by the author into scientific circulation, which certainly enriches Ukrainian source studies and broadens the research base of theory and history of culture. The documents found are stored in the archives of Ukraine and Europe: the Institute of Manuscripts, the Division for the formation of the 
NBUV Music Fund, the Berlin State Library (a work by E. Belogradskaya), the National Museum in Krakow (sonatas by M. Berezovsky) and in other archives of the world.

The source of the submitted intelligence was also archival materials stored in the Central State Archives of Higher Authorities and Administration of Ukraine (CDAVO of Ukraine), Central State Archives of Public Associations of Ukraine (CSAGO of Ukraine), Institute of Manuscripts of the National Library of Ukraine by V. Vernadsky (IR NBUV) - F.1 ("Figures of Ukrainian Culture"), Musical Society by M. Leontovych (F. 50), Museum of the History of Book and Printing of Ukraine, etc.

The submitted rare materials have scientific substantiation, analyzed from the point of view of modern cultural studies and art criticism, meet the tasks of the present in the field of science, culture and education. The study "Unique Manuscript and Printed Documents of Ukrainian Musical Culture of the 18th Century" will be useful for scientists, art critics, as well as in the educational process of art institutes in the courses "Theory and History of Culture", "History of Ukraine", "History of Ukrainian Music", "Source Studies".

\section{The Handwritten Heritage of Nicholas Diletsky, Elizabeth Belogradskaya, Maxim Berezovsky in the archives of Europe}

The assertion of independence of Ukraine as a sovereign state through the study of its cultural genealogy is relevant at the present historical stage of its development. The return of music of the past Ukrainian people is connected with the study of the manuscript book of the pre-printing period, which lasted longer for Ukraine than in Western Europe: only in the second half of the eighteenth century appeared the first printed notes that reproduced only domestic music. Therefore, searching for a handwritten musical heritage and bringing it into the information world through multimedia technologies is an important task of contemporary Ukrainian art criticism, on the one hand, and computer science, on the other.

Narrowing down the time space of the musical manuscript heritage to the period of copyright, we set the boundaries of the 17th-18th centuries, that is, the boundaries of the Baroque era and the domination of the choral partisan composition. The criterion for the selection of musical works for their installation in the Internet space is their uniqueness as a cultural heritage not only of the Ukrainian people, but of all humanity. The study of Ukrainian handwritten monuments of the notarial record, the possibility of access to their study is of great importance for the development of the world theory of music paleography. 
The features of baroque as a pan-European phenomenon in Ukraine first appeared in literature at the turn of the 16th-17th centuries. In Ukrainian musical art, Baroque was most striking from the middle of the seventeenth to the middle of the eighteenth century. During this period, polyphonic music of baroque style was formed in Ukraine, which by its high artistic level and national originality was not inferior to the achievement of Western European church music. Polyphonic singing in the seventeenth century in Ukraine was called partes from the Latin word "pars" (part, participation, party).

The party concert is a new style of church music, born of the Baroque era. It reflected new processes that have taken place in Ukrainian culture as a whole since the sixteenth century, namely: the growth of its connection with Western European cultures. Ukrainian partisan music creators were well aware of the concerto style of spiritual Catholic European music, which was born in the late 16th century in the works of the composers of the Venetian school Andrea and Giovanni Gabriel. Their choral works (six to sixteen voices) with instrumental accompaniment were called concerts. The concert style, formed in Venice, has spread to other regions of Italy, and then - in a number of European countries: in Germany in the works of G. Schütz, in Poland (composers M. Melchevsky, J. Ruzycki, etc.).

Having mastered the borrowed technique of concert choral writing, the composers created the Ukrainian style of partisan music that spread in Russia, Serbia. The originality of Partesian music was supported by its creators on the intonational features of the Ukrainian church monody and appeal to Ukrainian folklore sources. The party concert is one of the most remarkable achievements of the brightest period of Ukrainian culture of the 17th - the first half of the 18th century, its "golden age". At this time, the author's party concerts appear in the Ukrainian professional church music and the Ukrainian composer school is formed. The Kiev Collection of Party Music, held in the holdings of the National Library of Ukraine named after V. Vernadsky, contains works by Mykola Diletsky, Vasily Titov, as well as certified by the following authors: Davidovich, Dmitry Popov, Feodosii Svetly, Ivan Domaratsky, Herman Levitsky. The authorship of the individual Services is indicated by the names Mykola, Duma, Gritska.

Partesian compositions are mostly preserved in the form of vocalists, representing the record of one choral party. In most cases, records of one choral party are grouped into collections. Music records and collections of party concerts are decorated with screensavers, vignettes in the fields, frames with a vividly colorful accent. The artistic decoration of party concerts continues and develops the practice of excellent design of Ukrainian handwritten notinol irmologions. 
Party pieces in the messengers were recorded by Kyiv square notation. The size was set with the key, though the clock risks had not yet been taken. There are also no markings of tempo, dynamic shades. Occasionally, "quiet" or "loud" correspondence may occur.

Party books have manuscripts (marginalia) in the form of singers' lists and their notes, which provide interesting material about the existence of a party concert, the epoch of its functioning in society, and indicate the use and popularity of the work ${ }^{1}[2]$.

In Kiev, the Vernadsky National Library of Ukraine stores more than six hundred partes works (recorded in messengers) from the Kiev-Pechersk Lavra and Sofia. The manuscripts of these party concerts date to the last third of the seventeenth - first half of the eighteenth century. Their description and cataloging were carried out by Ukrainian musicologist N. Gerasimova-Persidska. Unfortunately, much of the catalog is in the manuscript. This complicates the study of the Ukrainian party concert as an achievement of world music art. The use of the UKRMARC format developed at the National Library of Ukraine named after V. Vernadsky with the participation of Valeria Shulgina and Olga Barkova for bibliographic recording of party concerts and exhibiting catalogs on NBUV website (www.nbuv.gov.ua/ep/) information about the Ukrainian handwritten musical heritage of the 17 th -18 th centuries.

The preparation of sheet music for partes concerts to be performed by contemporary choirs requires special textual work, as the way of fixing musical works in the vocal cords resembles the recording of dramatic works by roles. Full text restoration is a single piece of work. For partisan works, the composing of the score is related to the translation of the so-called "Kiev banner" of the note record into modern notation, which is complicated by the unclearness of the records, the descriptions of the scribes, the defect of the public speakers. Such sophisticated textual processing of primary sources requires information from other archives in Moscow, St. Petersburg, and Serbia (Novi Sad), which also contains collections of party concerts of the 17th -18 th centuries, that is, the possibilities of Internet connection with various storages of the world.

Translated into digital format the score of M. Diletsky's concert "Rejoice, maiden" is presented in the NBUV electronic library (www.nbuv.gov.ua/ep/). The audio recording of the "Rejoice, maiden" concert has been converted from music format to MP3 format presented on the Internet.

1 Instytut rukopysu Natsionalnoi biblioteky Ukrainy im. V. I. Vernadskoho, m. Kyiv (IP NBUV), f. KR 3, \# 39, \# 121184; f. KR 3, \# 38, \# 121185; f. KR 4, \# 36, \# 121036; f. KR 4, \# 34, \# 121034; f. 342, \#19; f. KR, \# 26, \# 120920; f. KR, \# 27, \# 120921 
Also presented is a digital format of the concert incite (fragment), which is necessary for the information of music documents in the electronic library ${ }^{2}$ [4].

Turning to the study of the past and bringing the most striking heritage of Ukrainian music culture into the world, we find the deep roots of our spirituality, of our national musical art's involvement in world civilization.

An important part of the instrumental national repertoire of the first half of the 18th century in Ukraine is the first works of great form, which became known to performers and educators through the research and search of domestic scholars of today. The pearls of the Ukrainian classical piano repertoire include the works of Elizabeth Belogradskaya and Maxim Berezovsky, found at the end of the 20th century.

Elizabeth Belogradskaya (1739 - after 1764) was a chamber singer and harpsichordist at the court of Empress Elizabeth Petrovna in St. Petersburg. Her father, Timothy Belogradsky, is mentioned by Jacob von Stelin in his book "Information on Music and Ballet in Russia" as a professional lute player, singer, and Belogradskya states that she is a virtuoso harpsichordist, the youngest daughter of the aforementioned lute player of Belogradsky. It is also known that Timothy Belogradsky as a talented bandura was brought to St. Petersburg from Ukraine ${ }^{3}$ [5].

Thanks to the scientific research of V. Shulgina and M. Stepanenko, a copy of the manuscript of E. Belogradskaya's "Minuet Startser's 8 Variations" was obtained from the Berlin State Library. Austrian musician Joseph Startzer (1726-1737) worked in St. Petersburg from 1757 to 1768 . He composed the ballets "Flora's Victory over Borei," "Apollo and Daphne," to ballet numbers at G. Raupach's Alcesta Opera and, with G. Raupach, the Shelter of Virtue, where Elizabeth Belogradskaya performed the main part. On the subject of one of these works, these variations were written. Quite a virtuoso style of variations, various techniques of variation, melismatics, harmony close to Haydn's works in the presence of original presentation of musical material. All this testifies to the remarkable composer and performance of Belogradskaya. Particularly attractive is the work performed on his harpsichord.

The Ukrainian repertoire was also expanded by the three sonatas found by V. Shulgina ${ }^{4}$ [5] at the National Museum of Krakow for Maxim Berezovsky's harpsichord: in C major, F major, C flat major.

${ }^{2}$ Shulgina V. Establihment of Multimedia Historic and Cultural Resource of Multipurpose Electronic Library. Elektronische Bildverarbeitung \& Kunst, Kultur, Historie. EVA Conference International. Berlin, 2002. P. 184-189.

${ }^{3}$ Shulhina V.D. (2007) Narysy z istorii ukrainskoi muzychnoi kultury: dzhereloznavchyi poshuk [Essays on the History of Ukrainian Musical Culture: A Source Study]. Kyiv: NAKKKiM. p. 14.

${ }^{4}$ Shulhina V.D. (2007) Narysy z istorii ukrainskoi muzychnoi kultury: dzhereloznavchyi poshuk [Essays on the History of Ukrainian Musical Culture: A Source Study]. Kyiv: NAKKKiM. P. 14-23. 
Maxim Berezovsky (1745-1777) was born in Hlukhiv, where the residence of the last Ukrainian hetman Kirill Razumovsky was located at that time. M. Berezovsky studied first at the Hlukhov Music School, then at the Kyiv-Mohyla Academy, formed as a musician in Ukraine. In his youth he moved to St. Petersburg, where he performed in the chapel of Grand Duke Peter Fedorovich, then in the court of Italian troupe. The troupe was able to interact with prominent musicians in Europe. He stayed in Italy for more than three years (1769-1873). Extraordinary talent (besides composing activity, performing in opera, playing violin, harpsichord) contributed to his recognition in the very center of European musical culture - Italy. Berezovsky successfully completed his studies at the Bologna Philharmonic Academy, had the opportunity to get acquainted with Leopold and Wolfgang Amadeus Mozart, who in 1767 visited Bologna to obtain the title of Bologna Music Academician for young Wolfgang. The Italian period was the happiest in the work of the composer: his opera "Demofont" was staged, which was a great success. The return to Russia brought disappointment and premature death.

The name of Maxim Berezovsky, a prominent Ukrainian composer, is associated with many legends. During his life in various countries, the tragic early death of the composer caused the dispersion of his handwritten inheritance and the possibility of discovering new works previously unknown to the composer.

Yes, there are only excerpts from the opera of the master "Demofont", which are stored in the library of the Florence Conservatory. Cherubini (copies at the State Museum of Music Culture named after M. Glinka in Moscow); six sheets from the Padre Martini archive related to M. Berezovsky's name are in the City Music and Bibliographic Museum at the Bologna Municipal Library (copies at the M. Rylsky Institute of Art, Folklore and Ethnology of the NAS of Ukraine in Kiev) ), a handwritten copy of the Sonata for Violin and Harpsichord is stored in the Music Department of the Paris National Library (storage code D 11688).

Researcher of instrumental creativity of M. Berezovsky Ukrainian scientist Mykhailo Stepanenko ${ }^{5}$ [8] provides interesting information about this work, which represents a previously unknown branch of the heritage of a prominent composer. The title page of the manuscript certifies that the Sonata for violin and chebalo was written by Academician Maxim Berezovsky, who is in the service of her Majesty the Empress of All Russia. Judging by the inscription "Pisa 1772", it is possible that M. Berezovsky created this Sonata during his stay in Italy in 1772 in the city of Pisa. In the left vertical corner of

${ }^{5}$ Stepanenko M. (1995) Sonata dlia skrypky i chembalo Maksyma Berezovskoho [Sonata for violin by Maxim Berezovsky].Ukrainskyi muzychnyi arkhiv. Kyiv: Tsentrmuzinform. P. 6. 
the title we find another mark - Partie de piaNo. Accompanying instruments could be in the Sonata - depending on the circumstances - harpsichord, clavichord, organ, and piano (the use of the cello as an accompanying instrument is not excluded).

The first performance of the Sonata took place in the twentieth century, namely: May 26, 1981 at the Kiev Conservatory. Performers - Alexander Panov (violin) and Mikhail Stepanenko (piano).

And here is Berezovsky's new discovery as an author of clavier music. A handwritten copy of three sonatas for a harpsichord solo major, a major, and a major from the Chartoryski Library, located in the National Museum in Krakow, was submitted to the V. Vernadsky National Library of Ukraine. The attribution of the handwritten copy was carried out by V. Shulgina ${ }^{6}[8]$ together with the RISM Center of Poland (National Library in Warsaw), its head Dr. Jolant Bychkowska-Staff.

The study used methods for analyzing related sciences. Mostly, these are methods of musicology, historical and musical source studies that reveal the origin, attribution, description, structure and content of documentary sources. The use of various forms of analysis contributed to the systematization of source material and its theoretical awareness.

Arguments for the attribution of sonatas were presented by V. Shulgina and discussed at conferences in Kiev "Ancient music: performance, research", at the Moscow Conservatory "Russian Archives Abroad", at the RISM congress in Frankfurt am Main ${ }^{7}$ [6].

A handwritten copy of the Three Sonatas for Maxim Berezovsky's Chebalo is stored at the Chartoriski Library at the National Museum of the City of Krakow in Poland. On the title page of the manuscript is indicated in Italian by 'Sonata Per il Clavircembalo Del. Sig. Ber [esowsky]'.

Three sonatas for chebalo, stored at the National Museum of Krakow, unveil and complement previously unknown facets of Maxim Berezovsky's work as an eminent master of 18th century instrumental music. The sonatas are written in the traditions of early classicism with great compositional skill and impeccable taste.

Studies of a handwritten copy of these sonatas in Poland together with the head of the national Polish group RISM, Dr. Jolant Bychkowska-Staff,

${ }^{6}$ Stepanenko M. (1995) Sonata dlia skrypky i chembalo Maksyma Berezovskoho [Sonata for violin by Maxim Berezovsky]. Ukrainskyi muzychnyi arkhiv. Kyiv: Tsentrmuzinform. P. 8.

${ }^{7}$ Shulhyna V.D. (2002) Notniyi arkhyv Razumovskykh v kontekste evropeiskoi kulturi vtoroi polovyni XVIII veka [Razumovsky Music Archive in the Context of European Culture of the Second Half of the Eighteenth Century]. Russkye muzikalnie arkhyvi za rubezhom. Zarubezhnie muzikalnie arkhyvi v Rossyy : nauch. trudi Moskovskoi hos. konservatoryy im. P.Y. Chaikovskoho. Moskva: Moskovskaia hos. konservatoryia ym. P.Y. Chaikovskoho. Sb. 31. P. 37 
revealed the following. The ink used to write the note text is bronze in color. The sheets are made with a $5 \mathrm{~mm} 5 \mathrm{~mm}$ metal grid. Number of notebooks per page -8 . Size $285 * 230 \mathrm{~mm}$.

The notes of all three sonatas are written in one hand. An analysis of the paper and the nature of the note-writing conducted by Polish experts from the RISM national group of Poland indicate that the manuscript was made in the second half of the 20th century (Dr. Jolanta Bychkowska-Staff). The involvement of various forms of paper analysis and sheet music made it possible to take the attribution of these works to a new level and identify ways of their being in the Chartoriski library. A comparison of the Sonatas with the autograph of Berezovsky (the autograph of the antiphon - the composer's examination work of May 15, 1771, which has survived until now) shows that the copy of the Sonatas was made by a copyist.

Repeated performance of the mentioned Berezovsky sonatas on the harpsichord by Professor Svetlana Shabaltina at the Department of Ancient Music of the National Academy of Music (Kyiv), at a conference at the Moscow Tchaikovsky Conservatory of Music, at concerts in the Kyiv Philharmonic Orchestra, these works belong to the best pages of the European chamber music of the 18th century.

The Sonata for violin and harpsichord in C major, whose handwritten copy is kept in the Music Department of the Paris National Library, was invented by Michael Stepanenko. Comparison of the three Sonatas for clavir with the above Sonata for violin and viola by Maxim Berezovsky confirms the opinion that these works belong to the pen of one author.

How could these manuscript copies of Berezovsky's works be found in the Chartoriski library?

Chartory or Chartoryzhsky - the famous princely family in Lithuania, then in the Lithuanian-Polish state in the 18th century had such a high position in the Commonwealth that their fate depended on them. The Czartoryski Party, which used the royal court's favor, sought support in Russia, unlike Potocki.

The Princes of Czartoryski had one of the richest libraries in Europe, known in the seventeenth century, which was housed in the city of Pulawy, Poland. The library contained 15,000 volumes and the number of manuscripts reached 1558. Adam-Casimir Chartoryski (1734-1823), a prominent Polish figure, was a candidate for the Polish throne, but declined in favor of his cousin Stanislav Poniatowski. Adam-Casimir Chartoryski as a person is very educated and the commandant of the Warsaw Cadet Corps has done a lot for the development of education in Poland. He is the author of several literary works that have been published. He received Emperor Alexander in Pulawy, was close to the Russian imperial court. 
His sons Adam-Yuri and Constantine-Adam received excellent education and were sent to Europe and then to St. Petersburg to complete it. There was a close friendship between Grand Duke Alexander Pavlovich and the Chartory brothers. Adam-Yuri was governor of the Ministry of Foreign Affairs of the Russian Empire until 1807. He is the author of many literary works. There are also many works on Adam-Yuri Chartorysky. Thus, the guardianship of education, interest in replenishing the family library with manuscripts, involvement in Russian culture, travel to Europe, during which the Chartori replenished the family library, as well as family proximity to Count Alexei Razumovsky through the father of General Repnincontribute to the purchase ofcircumstances, when the latter was in the prime of its glory in Italy and the production of the opera Demofont in Livorno (1773).

Research of Documents from the Fund \# 441 of the Central State Museum-Archive of Literature and Art of Ukraine (CDAMLM of Ukraine) "Materials of Art and Literature Workers of the 17th - 19th Centuries. Collection" confirmed the possibility of further source-finding findings from the heritage of Maxim Berezovsky. The materials of the collection of the former Library of the Singing Academy in Berlin (Zing-Akademie zu Berlin), which was rescued and exported to Ukraine at the end of World War II, and soon returned to Germany, include unique manuscripts and old printed works of the most famous European musicians. The most valuable part of it is the autographs, lifetime copies and first prints of the works of composers from the Bach family.

A guide to the fund \# 441 of the Central Art Museum of Ukraine, a catalog of the library stock of the Kiev Conservatory, compiled in about 1946, served as a catalog. The following entry was made under number 907; "Handwritten Vocal Parts of the Spiritual Concert" The Beneficial Joseph".

Case number 907 consists of six volumes. Twenty-eight anonymous choral works, comprising the contents of six volumes of manuscript parties, belong to Baldazar Gallup and Maxim Berezovsky. The newly found works of Berezovsky are a real base for updating his creative biography, publishing a new collection of the composer's choral heritage, performing, musicological, historical and theoretical studies.

This manuscript contains all of Maxim Berezovsky's concerts published and known at the time (except Unser Vater), the liturgy (No. 10), the sacrament verse (No. 14) and works that were considered lost and known only by titles, sometimes and by initial cycles (incipes).

Thus, the searches and findings of Ukrainian musicologists at the turn of the 20th-21th centuries confirmed the possibility of further source-discovery of unknown pages of creativity of Ukrainian Mozart - Maxim Berezovsky. 


\section{The Music Archive of the Razumovsky Family in the Context of Ukrainian and European Culture}

The Music Division of the National Library of Ukraine named after V. Vernadsky (NBUV) has been recording music since the seventeenth century. Among the rare and unique documents are the music collections of the last three centuries. Thus, the 18th century was represented by a notation of the Razumovsky family (the last hetman of the Left Bank Ukraine and its descendants), of the 19th century represented by the personal library of Gavrushkevich (more than 500 units of preservation), an amateur musician who left his fruitful trace in the history . The end of the 19th - beginning of the 20th century is represented by a collection of records (more than 500 units), among which are the first records of the most prominent performers of the world level, a collection of S. Maslov's records (more than 1700 units). Of noteworthy value is the musical manuscript collection "Music Fund of the Union of Composers of Ukraine", which contains autographs and manuscript copies of not yet published works of contemporary Ukrainian composers (1400 storage units) transmitted to NBUV by the Ministry of Culture from the libraries of the Muzfund and the National Union of Composers of Ukraine ${ }^{8}$ [3].

The Razumovsky's Music Archive was submitted to the Library of the University of National Art in 1918. This is one of the most interesting private music collections among those stored in music libraries in the world. The total volume of the collection is 1682, of which 356 are manuscripts. Notes from the Razumovsky Collection represent works by professional musicians of the 18th - early 19th centuries - composers of prominent, famous, little known, forgotten and unknown. The represented music belongs to different styles, genres, forms and composing schools.

This unique collection, collected with such taste and knowledge of the world music culture, was accumulated by our compatriots - Razumovsky, whose roots are among the Ukrainian Cossacks. The father of the founder of the library of the Ukrainian hetman Kirill Razumovsky (1728-1803) was the registrant Cossack of the Kiev Vyshgorod Kozelets Grigory Razum.

The sons of the last hetman of Ukraine were also prominent statesmen and highly educated amateur musicians, continuing the accumulation of the music library. Most of the collection belonged to the eldest son of Hetman Alexei (1748-1822), who was Minister of Public Education. The youngest son Andrew (1752-1832) became famous as a talented diplomat, serious amateur musician and philanthropist. In 1808 he organized a quartet in Vienna, which

${ }^{8}$ Ivchenko L. V. (2004) Rekonstruktsiia notnoi kolektsii O. K. Rozumovskoho za katalohamy XVIII st. [Reconstruction of O.K.Rozumovsky's music collection according to the catalogs of the XVIII century]. Kyiv: HAH Ukrainy im. B. I. Vernadskoho. P. 4. 
became the first permanent ensemble in Europe. The Great Beethoven dedicated the Count Andrei Razumovsky Quartet op. 59, No. 7-9, where Ukrainian folk songs were used.

The owner of most of the collection was Alexey Razumovsky (17481822), a person with European education, the eldest son of the last hetman of the Left Bank Ukraine, Kirill Razumovsky. According to contemporaries, Alexei was also the owner of Russia's richest natural sciences library (after his death, it was auctioned off in the early 19th century). The notes in his collection were carefully cataloged by librarians of the eighteenth century. The collection also included notes that were believed to belong to other members of the Razumovsky family (Alexei Grigorovich and Kirill Grigorovich) and descendants of O.K. Razumovsky along the lines of Repnin.

The manuscript part of the collection has two major sections: vocal-stage and chamber-instrumental music.

The first and most valuable section includes manuscripts representing different types of vocal, stage and vocal music (about 100 copies). Basically, these are handwritten scores of operas, cantatas, oratorios of composers of the 18th century. Almost all of them are copies made by professional transcribers of notes, but they can fairly be attributed to rare sources. The rarity of each score is further enhanced by the fact that, according to the traditions of its time, even the works of the same author with the same name sometimes had certain differences (for example, insert numbers or notes, other variants of musical text). The manuscripts of the scores of the vocal and stage works have been partially introduced to the scientific circulation (since the 1920s such wellknown scientists as O. Dzbanivsky, A. Preobrazhensky, Y. Keldysh, R. Pekelis, T. Livanova, V. worked with them. Protopopov, T. Schaeffer, K. Cherpukhova, L. Ivchenko, V. Shulgina, etc.). Among the particularly valuable scores stored in the collection are two operas by the Italian composer Genaro Astaritta, who, according to scientists, worked with Alex K. Razumovsky in 1786-1787. These are the opera The Wanderer (1786, in Russian, The Wanderer, the text by Knyazhnin) and The Deserted Island (1787).

The manuscripts of these operas, as indicated on the title page, are autographs of Astaritta. Excerpts from the opera The Wanderer were published in musicology literature (from the 1940s), performed in concerts. Among the handwritten copies of particular importance are the operatic pastiche "Serenade" (in Italian) and "Cantata in honor of the Russian Tsar Alexander" Fr. Marrakech ${ }^{9}[1]$.

${ }^{9}$ Arkhiv Natsionalnoi biblioteky Ukrainy im. V. I. Vernadskoho, m. Kyiv (Arkhiv NBUV), f. 1, op. 1, od. zb. \# 35, Dzbanivskyi O. T. Muzychna biblioteka Rozumovskoho O. K. (z arkhivu notnoi biblioteky UAN) [Dzbanivskyi OT Music library of Razumovsky O.K. (from the archive of the UN Music Library)], 89 ark. 
The opera "Serenade" is represented by a set of orchestral voices (1747, in Italian "Serenata"). Its authors are King of Prussia, Frederick the Great, and his court musicians Graun, Kwantz, and Nickelman. The opera was reissued in the late XIX and early XX centuries. A copy of the opera in the Razumovsky Collection, made in the eighteenth century from the original, is today the second primary source of its study. A copy of the opera was probably donated personally by Frederick the Great Kirill Razumovsky during his stay in Berlin. An interesting but unattributed source was put into scientific circulation in 1970.

A clean (calligraphic) copy of "Cantatas in Honor of Russian Tsar Alexander ..." (Leipzig, 1813) is made from the autograph of the Italian composer Fr. Morlakki. The cantata was commissioned by the composer with the assistance of M. Repnin (the son-in-law of O. Razumovsky, at the time of the cantata's creation he was governor-general of Saxony). The autograph was not preserved. Of particular value are the copies of the operas by Anfossi and J. Sarti, who worked at the court of Catherine the Great (the originals of these works are kept in St. Petersburg).

Most of the manuscripts in the collection (about 250 copies) belong to chamber instrumental music. Preferably, these are copies of professional copyists or printers of the eighteenth century. By genre characteristics - it is chamberinstrumental music for ensembles of different composition (duets, trio, quartets, etc.), symphony orchestras (concerts, concerts, symphonies). Chronologically - from the 1930s to the beginning of the 19th century. Manuscripts, along with editions of the XVIII century, are of interest to performers and musicologists. The music from the chamber-instrumental section of the Razumovsky Collection has been played on the concert philharmonic stage since the 1940s. The handwritten notes of chamber instrumental music attract the attention of musicologists. This is not only a study, but also the publication of certain monuments (the works of J. H. Bach, D. Paeziello, etc.). Separate works from the chamber-instrumental part of the collection have been introduced to scientific circulation since the 1920s (O. Dzbanivsky, T. Sheffer, K. Cherpukhova, L. Ivchenko, T. Hnatov, B. Suta, Y. Rudchuk, V. Shulgina).

Various libraries of the world hold scores (autographs and copies) similar to those found in the Razumovsky's music collection. The number of such copies of one opera is from one, but almost never exceeds 20 copies in the world. The scores from the Razumovsky's Collection may accordingly be the second, third, and so on. The rarity of each score is further enhanced by the fact that, according to the traditions of its time, even the works of the same author with the same name could have certain differences (for example, insert numbers, notes, other variants of musical text). Most of the manuscripts have never been published, and the major part of the notes are rarities. 
The Razumovsky's Music Library recreates the musical atmosphere of classicism in Europe and, along with a reflection of the works of J. Haydn, V.A. Mozart, L. Beethoven, gives an exhaustive picture of the works of the littleknown composers of the eighteenth century known in our time. Thus, rare editions of works by composers J. Stamitz, K. Stamitz, H. Kanabih, F. Richter, A. Fils, D. Toeski, V. Kramer, T. Frenzl are represented in the collection by the Mannheim School, which played at the end of the 18th century role in the formation of the composing and performing style, which became the harbinger of the Vienna classical school. The collection also presents the composing schools of the 18th century in almost all European countries - Austria, England, Belgium, Italy, Germany, Poland, Russia, Ukraine, France, Czech Republic ${ }^{10}$ [7].

An important factor in the perception of Razumovsky's notations as a collection is the presence of eight hand-written catalogs of Alexey Razumovsky's Music Library, which are well preserved and give a bibliographic description of editions and manuscripts of chamber and instrumental music. These catalogs are the first perfect sample of the national music bibliography, have no world-class analogue, but, unfortunately, have not yet become a property of mankind, because they have never been published and their information is not available on the computer network. Catalogs compiled on the territory of Ukraine by an unknown author, are a unique monument of the world music bibliography, a reflection of the culture of Ukraine in the second half of the 18th century.

Catalogs are compiled on a systematic and alphabetical basis, based on the systematics of the genre of chamber instrumental music. The incipient inscribed in each work gives the right to refer these catalogs to the unique bibliographical directories of the eighteenth century, which are of world importance.

The catalogs are designed as a handwritten book on paper, the entries are made in French, and the designation is in Italian. Title page - handwritten but decorated with an engraved illustrated frame depicting the emblem of the Russian Empire, two laurel-wrapped columns, angels, etc. The binding is primordial and made in Rozumovsky's workshop. It's cardboard in light brown leather. On the covers - monograms with gold embossed "ACP" (Alexey Razumovsky in Russian) under the graph column. All handwriting directories have the same look and make the reader a striking aesthetic impression. Among the monuments of Ukrainian music from the Razumovsky's Collection, the Ukrainian Symphony draws attention.

${ }^{10}$ Shulgina V., Yakovlev O. (2004) Presentation of Ukrainian Old Printed Book and Music Manuscripts of the Orthodox Church in the Digital Space // Electronic Imaging \& the Visual Arts. EVA 2004 Florence. Bologna: Pitagora Editrice, 2004. P. 8. 
The 18th Century Ukrainian Symphony, also known in musicology as "The First Ukrainian Symphony by an Unknown Author," was published in the Journal de musique, dedle aus Dames: Pour le mois de Octobre. This magazine was published in St. Petersburg by Baron Ernst Vanjur. The full name of the journal "Journal de musique pour le clavesin ou pianoforte, dedle aus dames par B.W. amateur "(Music for harpsichord or pianoforte dedicated to ladies b (aron) B (anjura), amateur). It was the October issue of Music Magazine ... that remained the only known specimen in the world and is stored in the NBUV Music Formation Division among other unique documents of the Razumovsky's Collection as an outstanding monument of Ukrainian culture ${ }^{11}$ [4]. The copy was restored in January 1993.

The author of the Ukrainian Symphony, featured in the October issue of Music Magazine ..., is Ernest Vanjura, a Czech native of Waneberg, a harpsichordist, composer, publisher who served in the Imperial Theaters Directorate . There are two other Vanura's symphonies, Russian and Polish, in which the author also used Ukrainian songs.

Performing works by the leading artists of Ukraine works from the Razumovsky's collection becomes a real sensation, because the music of littleknown composers is performed in Ukraine for the first time and greatly enriches the artistic life of professional musicians and amateurs.

Becoming Ukraine as a sovereign state calls for our country to enter the world information space. Today, Ukrainian art is experiencing a time of national revival and awareness of Ukraine's cultural heritage in the context of world value criteria. The new cultural policy attaches great importance to the study of Ukrainian musical culture in a global context and extrapolation of national achievements into a system of universal values. Familiarizing the world with such Ukrainian treasures as the Razumovsky's Music Library will help our art enter the global information space.

\section{CONCLUSIONS}

The process of revival of Ukrainian statehood requires not only the development of a modern political and economic system of Ukraine, but also a comprehensive study of its culture. To date, the problem is the return to the Ukrainian people of all spiritual values created by previous generations.

In this context, it is important to explore the unique memorial artdocuments of Ukrainian culture of the eighteenth century. Through the cultural traditions reflected in the handwriting and print heritage, communication between epochs and generations is made. Knowledge of one's

11 Shulgina V. (2002) Establihment of Multimedia Historic and Cultural Resource of Multipurpose Electronic Library. Elektronische Bildverarbeitung \& Kunst, Kultur, Historie. EVA Conference International. Berlin. P. 184 
ancestry, historical and cultural heritage contributes to the raising of national consciousness.

Respect for historical memory, the growth of historical consciousness and the pursuit of truth make one consider the history of outstanding manuscripts and prints as an organic phenomenon inherent in the culture of Ukraine. Numerous archival documents, rare publications, other source materials are needed to reproduce the true history of our country, determine the main ways of restructuring the national cultural policy and outline the prospects for the development of cultural processes in Ukraine in the 21st century. culture of Ukraine.

The crucial stages of human history are characterized by a radical transformation of the categorical model of the world. In the late twentieth early 21st centuries on a world-wide scale, and such transformation occurs. The formation of a new model of the world occurs as a consideration of its various projects.

The genotype of global civilization was emerging in the Euroregion as a transformation of traditional cultures. Each era of the evolution of historical and philosophical thought left its mark on the formation of civilization. . The idea of personality autonomy, its self-worth, necessity and possibility of selfrealization is formed.

Therefore, the modern process of national development is characterized by the absorption of universal values. But it is not meant to reduce the national to the universal, but to acquire the ethnos the value of the national hypostasis of humanity, to uncover national archetypes in the context of their universal components.

Through the prism of the formation of a new scientific paradigm, the information space is regarded as a spiritual and energy information space, which ensures the entry of a person into a new socio-cultural field on the principles of compatibility, complicity and enrichment of ethnocultures.

Awareness of a new situation related to the creation of a technological society and its transition to an information one requires the development of an appropriate scientific paradigm of modern theory and history of Ukrainian culture. This is due to the evolution of modern philosophical views, according to which the center of the scientific picture of the world becomes a person with its search for the meaning of life, freedom of choice, self-actualization, creativity, ways of managing their own development. The humanization of culture involves processes of integration and differentiation, that is, the acquisition of progressive foreign experience and the preservation and development of their own national cultural heritage and traditions, in particular in the field of research and introduction into the scientific and cultural circulation of monuments of national history. 
The digital presentation of music collections in the scientific electronic library, along with historical, art and bibliographic studies, envisaged the development of technology for creating digital copies and multimedia applications, which provided not only the visual display of handwritten notes and printed music materials, but also electronic media. reproduction of fragments (incites) or completely some works from the Ukrainian musical heritage. Music subscripts are considered as elements of the search engine of the Scientific Electronic Library, and sound reproduction of certain music works as a network digital library of musical materials.

\section{SUMMARY}

The present article is based on the problem of research and introduction into the scientific and cultural circulation of rare note manuscripts and rare editions that make up the treasury of Ukrainian national culture and are of world importance. A source search led the author of the article to demonstrate and analyze individual artdocuments of Ukrainian music culture. Among them are Mykola Diletsky's party concerts, which are stored in the funds of the National Library of Ukraine by V. Vernadsky (NBUV); handwritten variations of Elizabeth Belogradskaya as an example of the first large-scale Ukrainian work (autograph at the Berlin State Library); Maxim Berezovsky's Three Clavier Sonatas from the National Museum in Krakow; note collection of the Razumovsky's family in NBUV funds. The article presents the attribution and scientific analysis of the presented documents of Ukrainian musical culture of the 18th century.

\section{REFERENCES}

1. Arkhiv Natsionalnoi biblioteky Ukrainy im. V. I. Vernadskoho, m. Kyiv (Arkhiv NBUV), f. 1, op. 1, od. zb. \# 35, Dzbanivskyi O. T. Muzychna biblioteka Rozumovskoho O. K. (z arkhivu notnoi biblioteky UAN) [Dzbanivskyi OT Music library of Razumovsky O.K. (from the archive of the UN Music Library)], 89 ark. (in Ukrainian).

2. Instytut rukopysu Natsionalnoi biblioteky Ukrainy im. V. I. Vernadskoho, m. Kyiv (IP NBUV), f. KR 3, \# 39, \# 121184; f. KR 3, \# 38, \# 121185; f. KR 4, \# 36, \# 121036; f. KR 4, \# 34, \# 121034; f. 342, \#19; f. KR, \# 26, \# 120920; f. KR, \# 27, \# 120921. (in Ukrainian).

3. Ivchenko L. V. (2004) Rekonstruktsiia notnoi kolektsii O. K. Rozumovskoho za katalohamy XVIII st. [Reconstruction of O.K.Rozumovsky's music collection according to the catalogs of the XVIII century]. Kyiv: HAH Ukrainy im. B. I. Vernadskoho. 644 p. (in Ukrainian). 
4. Shulgina V. (2002) Establihment of Multimedia Historic and Cultural Resource of Multipurpose Electronic Library. Elektronische Bildverarbeitung \& Kunst, Kultur, Historie. EVA Conference International. Berlin. P. 184-189.

5. Shulhina V.D. (2007) Narysy z istorii ukrainskoi muzychnoi kultury: dzhereloznavchyi poshuk [Essays on the History of Ukrainian Musical Culture: A Source Study]. Kyiv: NAKKKiM. pp. 14-23. (in Ukrainian).

6. Shulhyna V. D. (2002) Notniyi arkhyv Razumovskykh v kontekste evropeiskoi kulturi vtoroi polovyni XVIII veka [Razumovsky Music Archive in the Context of European Culture of the Second Half of the Eighteenth Century]. Russkye muzikalnie arkhyvi za rubezhom. Zarubezhnie muzikalnie arkhyvi v Rossyy : nauch. trudi Moskovskoi hos. konservatoryy im. P. Y. Chaikovskoho. Moskva: Moskovskaia hos. konservatoryia ym. P. Y. Chaikovskoho. Sb. 31. pp. 37-41. (in Russian)

7. Shulgina V., Yakovlev O. (2004) Presentation of Ukrainian Old Printed Book and Music Manuscripts of the Orthodox Church in the Digital Space // Electronic Imaging \& the Visual Arts. EVA 2004 Florence. Bologna: Pitagora Editrice, 2004. P. 8.

8. Stepanenko M. (1995) Sonata dlia skrypky i chembalo Maksyma Berezovskoho [Sonata for violin by Maxim Berezovsky] // Ukrainskyi muzychnyi arkhiv. Kyiv: Tsentrmuzinform. P. 6-8. (in Ukrainian).

Information about the author: Shulgina V. D., orcid.org/0000-0001-6007-2901 Doctor of Art Criticism, Professor, Professor of the National Academy of Culture and Arts Management 9, Lavrskaya str., 01105, Kyiv, Ukraine 